\title{
Modeling of Students Online Social Presence on Social Networking Sites with Academic Performance
}

\author{
https://doi.org/10.3991/ijet.v15i12.12599 \\ Yahya M. Aldheleai $\left({ }^{凶}\right)$ \\ Universiti Sains Malaysia, Penang, Malaysia \\ yamohd3egmail.com \\ Zaidatun Tasir, Waleed Mugahed Al-Rahmi \\ Universiti Teknologi Malaysia, Johar Bahru, Malaysia \\ Mohammed A. Al-Sharafi \\ Universiti Malaysia Pahang, Pahang, Malaysia \\ Alamin Mydin \\ Universiti Sains Malaysisa, Penang, Malaysia
}

\begin{abstract}
Social Presence is a vital component of learning experience. This study develops a predictive model of students' online social presence on social networking sites "SNS". This study used SmartPLS software in the model development process. The study explored five facets of SP and its relationship with students' academic performance. The model is based on the survey data that collected from tertiary students in Malaysia. The findings of this study showed that there is a significant relationship between all five facets of online social presence and students' academic performance. SNS is appropriate tools that supports students' sense of social presence which contributes to better learning and academic performance. Consequently, the developed model can be used by instructional designers, instructors, and researchers to measure students' online social presence and its effect on students' academic performance.
\end{abstract}

Keywords-Online Social presence, SNS, academic performance

\section{Introduction}

Social presence is the feeling of being there with a real person during online interaction [1]. In education, social presence is when students perceive that they are connected with others in online learning environment [2]. Hence, students' connection with other course participants is reflected on their motivation to take an active role in the learning activities process [3]. Previous studies argued that students involve more in learning when they are connected with others in playing an active role in their learning process [4]. Therefore, social presence seen to be an effective factor to positive students' performance in learning [5], and satisfaction [6]. 
Previous studies presented various types of both text expressions and emoticon that represent facial expressions which show social presence in online learning environment. For example, Rourke, Anderson, Garrison, and Archer [7] come out with a manifesto that distributed ten social presence expressions under three main social presence categories that commonly used in learning through computer conferencing. First, effective category which include emotion expression, use of humor and self-disclosure. Second, interactive category is shown by continuing discussion thread, quoting from others' messages, referring explicitly to others' messages, asking questions, expressing appreciation and agreeing with others. Third, cohesive category is presented through addressing participants name, addressing oneself or others by group, inclusive pronouns and salutation [7]. Including the mentioned segments, [2] proposed 30 indicators of social presence in online learning environment as shown in table 1.

Table 1. Proposed affective indicators in online social presence based on literature review.

\begin{tabular}{|c|l|c|l|}
\hline No & \multicolumn{1}{|c|}{ Indicator } & No & \multicolumn{1}{|c|}{ Indicator } \\
\hline 1 & User's characteristics & 16 & Negative response \\
\hline 2 & Vocatives & 17 & Familiarity with recipient \\
\hline 3 & Address by group name & 18 & Express belief and value \\
\hline 4 & Privacy & 19 & Quote from other's messages \\
\hline 5 & Salutations & 20 & Refer explicitly to other's messages \\
\hline 6 & Personal address messages & 21 & Express compliment, appreciation \\
\hline 7 & Psychological attitude toward technology & 22 & Phatic communication \\
\hline 8 & Use emoticon and paralanguage & 23 & Acknowledgment \\
\hline 9 & Express feeling or emotion & 24 & Informal and formal \\
\hline 10 & Timely response relationship & 25 & Continuing a thread \\
\hline 11 & Use humor & 26 & Trust relationship \\
\hline 12 & Self-discourse & 27 & Social relationship \\
\hline 13 & Express agreement & 28 & Social sharing \\
\hline 14 & Express disagreement & 29 & Social motivation \\
\hline 15 & Positive response & 30 & Value \\
\hline
\end{tabular}

Therefore, Sung and Mayer [2] developed their questionnaire instrument which

known as Online Social Presence Questionnaire (OSPQ) to measure the listed 30 social presence indicators under five categories with 19 items. However, some indicators were combined and measured by one item in the questionnaire. Sung and Mayer five facets are social respect, social sharing, open mind, social identity and intimacy.

Reviewing the related literature showed that most of previous studies on social presence focused on content analysis, as part of community of Inquiry (CoI) model or measuring learners or teacher's social presence using questionnaires. Therefore, more research is needed to develop a research model that shows how significant are the impact of social presence in online environment on learners' performance. Consequently, the researchers in this study is working to fill the gap in the related literature and develop model of social presence and student's performance through 
structural equation modeling method applying Partial Least Squares approach using SmartPLS modeling techniques.

\section{SP Five Facets in the Literature}

\subsection{Intimacy}

Intimacy is a type of interpersonal interaction which can be expressed by verbal or non-verbal gestures like eye contact and facial expressions [8]. According to Argyle and Dean [8] high level of intimacy strengthen the level of familiarity and trust which encourage the start of interaction and its continuation with more self-disclosure. Therefore, intimacy considered as the self-confidence of the depth of the attachment between partners [9]. Tardy [10] argued that certain level of intimacy is required for individual to rapport and strike up conversation. [11] asserted that individuals get to know about each other, exchange personal information and establish trust when they disclose personal information. Rourke et al., [7] categorized sharing personal information, emotions and feeling under effective expressions that reduce individuals' sense of isolation and encourage engagement in more dialogue.

Sung \& Mayer [2] explained that intimacy is about sharing personal life stories, emotion and feelings with other learning community. It reflects the deeper relationship and high sense of safety and trust toward the instructor and other participants. When students engage in intimacy feeling they seems willing to disclose more personal life stories and feel better when he/she share emotions with online learning community [2]. However, in this study, the respondents were asked about sharing personal life stories or emotions that linked to the learning topic as recommended by [4]. Therefore, intimacy survey statements were adopted to consider cultural conception in the context of this study that still conservative in terms sharing personal life stories which seen to be personal and not related to or shared for learning purpose [4].

\subsection{Social identity}

Students sense of social presence is fostered when they feel their identity is recognized by other learning participants. Students' social identity in online environment can be addressed through posting messages that include greetings and addressing their names [2] or through inclusive pronounce "We or Us" [12] . Therefore, Chen [13] recommended instructors to be personal, greet students and address their names in a way that encourage students to do that same with the instructor and peers. Students learn their peers names either directly through exercises or indirectly when they hear the instructor address classmates by names through which peers interaction can be fostered [14]. It was found that greeting and salutations, addressing participants by names, addressing inclusive pronounce (group reference) is indicator of open communication which foster group cohesion where students feel as part of the group [15] and [12]. Therefore, sharing greetings in 
instructor and students posts with instructor and peers awareness of student identity through addressing students names are imperative to boost students sense of presence [2].

\subsection{Open mind}

Open mind is the level of the understanding that shaped a person view and respect the difference with others' values, beliefs and opinion. Merryfield [16] defined open mind as the willingness to consider others experience, beliefs and perspective which is different from one's own. The importance of open mind according to [16] is that it helps learners to understand how other people think and act; learners also will be flexible to rethink their assumptions, identify misinformation and correct misconceptions. Open minded learners can flexibly agree or disagree with other's ideas in a constructive way [4]. Moreover, students with open mind can freely express emotions, feelings or ideas at the same time they are positive about providing feedback about others' ideas and opinion [2]. The mentioned open mind characteristics give learners an opportunity to get clear understanding of the discussed ideas, information and opinion as it passed through open discussion with asking questions, getting feedback and corrected information and conception. As a result, we look at open mind as a factor that support better learning with deep and clear understanding. Therefore, it is important for successful online learning to provide an atmosphere that encourage students to express their beliefs, values, opinion and to provide feedback and value others' feedback that enrich learning.

\subsection{Social sharing}

Instructors and students build social relationship through sharing personal information such as believes and values at the same time instructors can share their professional experience and interest with students as a way to motivate them to improve social presence in online environment [17]. Sung and Mayer [2] identifies the mentioned types of sharing as social sharing that enhance social presence in online learning environment. Social sharing according to Sung \& Mayer [2] is the case where students share personal information with others and feel free to express their values and belief [2]. Moreover, social relationship with peers and instructor, receiving encouragement and motivation from the teacher, sharing learning information [2]. John [18] claimed that such types of sharing reflect the common interests that shared among learning participants [18]. Showing of openness to others through sharing personal information, beliefs and values are types of affective expressions that shows teachers' immediacy in online learning environment [7]. Therefore, affective sharing was the essential components of learning community in which the participants enjoy high level of respect and trust [19] which foster students social presence. 


\subsection{Social respect}

Students' social presence can be improved when they are socially respected. Teachers' use of humor to gain students' attention, providing timely response to learners before and after class, acknowledging students active participation and asking questions are the behaviors that increase students sense they socially respected [20] and [15]. This type of open communication through which the teacher recognizing and complimenting students' contributions (Akyol and Garrison, [12] and Richardson et al. [21] lead to greater learning [22]. Accordingly, Sung and Mayer [2] included this types of behavior under social respect category of their study. Social respect according to [2] can be established through acknowledging students' posting questions and opinion during online discussion. Moreover, students feel they are socially respected when they receive immediate responses from their teacher, communicate with the instructor and exchange humor during their online conversation [2]. They claimed that these actions foster students' sense of social presence in online learning environment [2].

\section{SP and SNS}

SNS tools are highly accepted by students $[23 ; 24 ; 25]$ and fount to facilitate instructor online teaching roles [26] and student-student interaction [27]. Moreover, SNS such as Facebook and Twitter proved to be an environment that support students social presence $[26 ; 27 ; 4]$. Students' sense of SP can be improved through presenting their profiles and visiting other students profiles which consider as a way of communication and getting familiar with other classmates [30]. Therefore creating Facebook group to support new students transition from school to university contributed to the social cohesion among students; students could identify classmates with similar interest through visiting profiles [31]. Moreover, online contact and familiarity helped to improve face2face contact as they already overcome the anonymity in the first weeks of the course. SNS found to strengthen students emotional connectedness and mutual support among learning community members [32]. Hence, students expressed that interaction with the instructor and students through SNS enable them to be closure to them and encouraged to share personal interest, ask others for opinion with expecting support and timely feedback [32]. SNS was found to facilitate student's discussion which include social presence expressions. For instance, Baisley-nodine \& Ritzhaupt, [28] analyzed the content of students posts and discussion on SNS tool Twitter and found that $11.40 \%$ of students posts and discussion covered SP indicators that fall under affective response, interactive response and cohesive response [33].

\section{SP and Academic Performance}

Social presence found to have a positive impact in students perceived academic performance [26] [34] [35] in written assignment and the actual test [36] [37]. 
Moreover, higher sense of social presence is connected to more interaction with the instructor and peers [38] which positively improve students learning and academic performance [39]. However, the current study focus on the five facets of social presence developed by [2] in the context of online interaction via social networking site and how each facet predict students perceived academic performance in the developed predictive model.

\section{Objective}

1. This study aims to test the predictive model of five facets of SP and academic performance

\section{$6 \quad$ Methodology}

The researchers adapted Sung and Mayer [2] online social presence questionnaire to collect the data that measure social presence constructs. Some modifications were done to the questionnaire items to meet the online learning medium, context and purpose. Moreover, the intimacy construct indicators were amended to measure student's perception of sharing personal life stories that connected to learning content and experience rather than general personal life stories as recommended by [4] and [35]. Therefore, total of 19 indicators were employed to measure the five constructs. The constructs namely were intimacy, social identity, open mind, social sharing and social respect. However, students' performance construct items were self-developed by the researchers. The questionnaire was distributed to 200 tertiary education students in Malaysia. The returned cases were 189 which represent $95 \%$ of the distributed items. After removing the cases with missing data and outliers, a total of 181 cases were taken for the final analysis of the study. The raw data was keyed in SPSS software and the SmartPLS version 2.0 was used to establish social presence and performance model.

\subsection{Research Model and hypothesis}

Figure 1 show this study research model which shows the proposed relationship between five OSP patterns and students' AP. The patterns namely are Social Respect (SR), Social Sharing (SS), Open Mind (OM) Social Identity (SI), and Intimacy (I). The definitions of the included patterns are detailed in this section respectively.

The current study integrates the relevant factors which are social respect, social sharing, open mind, intimacy, social identity, and academic performance. Based on the factors and the thorough and literature review, the following hypotheses are developed and tested.

H1: There is a significant relationship between social respect and AP.

$\mathrm{H} 2$ : There is a significant relationship between social sharing and AP.

H3: There is a significant relationship between open mind and AP. 
H4: There is a significant relationship between social identity and AP H5: There is a significant relationship between intimacy and AP.

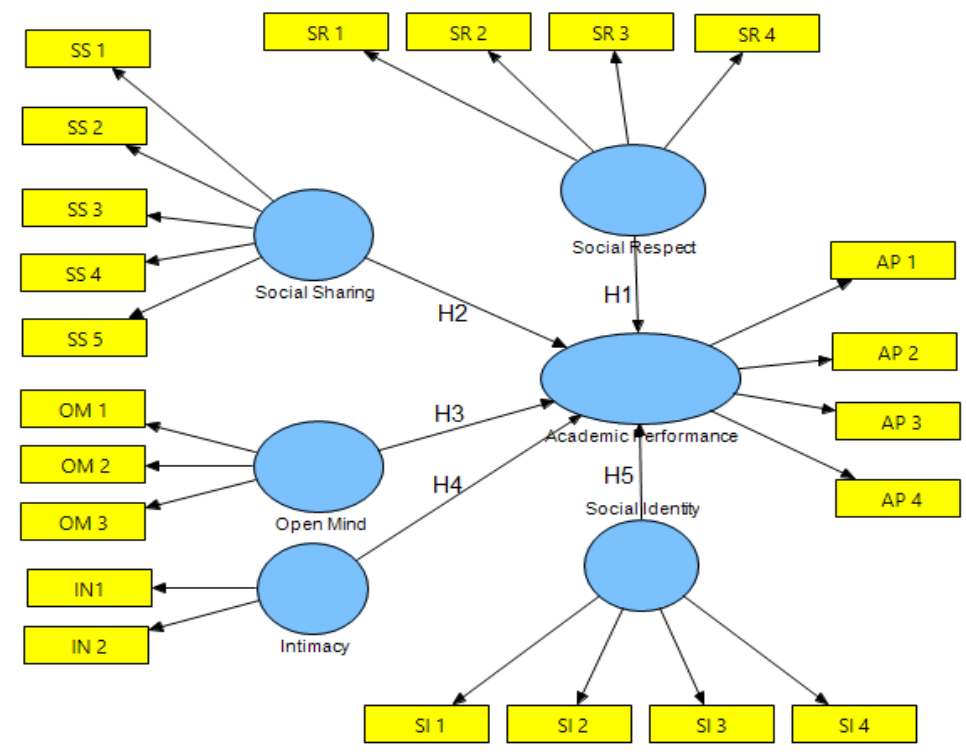

Fig. 1. Research Model

\section{$7 \quad$ Data Analysis and Findings}

\subsection{Measurement and instrumentation}

The beginning stage in the assertion of the legitimacy and dependability of the model is the use of the Partial Least Square. Basic Equations Modeling (PLS-SEM), Smart PLS 2.0. Preceding the theories were tried, two phases were used to affirm the fitness model's integrity. In like way, build legitimacy that spreads components loadings; composite unwavering quality, Cronbach's alpha, and merging legitimacy was determined. The recommendation given by Fornell and Larcker [40] considering making use of the standard test to affirm discriminant legitimacy was followed.

\subsection{Construct validity of the measurements}

Develop legitimacy is delineated as the level to which the things used to gauge a component can appropriately quantify the idea they were meant to quantify [41]. The entire things used to gauge the develops should stack essentially to their individual develops rather than different builds. This was guaranteed by leading an orderly audit of writing in the mission to deliver things that have as of now been set up and tried by earlier writers. On the premise of the component analysis, it was affirmed that things 
were reasonably named to their develops as they showed high loadings on them stood out from various develops as shown in table 2.

Table 2. Loading and cross-loadings of the items

\begin{tabular}{|c|c|c|c|c|c|c|c|c|}
\hline No & Variables & Code & SR & SS & OM & IN & SI & AP \\
\hline 1 & \multirow[t]{4}{*}{ Social Respect (SR) } & SR 1 & 0.831 & 0.000 & 0.000 & 0.000 & 0.000 & 0.000 \\
\hline 2 & & SR 2 & 0.818 & 0.000 & 0.000 & 0.000 & 0.000 & 0.000 \\
\hline 3 & & SR 3 & 0.858 & 0.000 & 0.000 & 0.000 & 0.000 & 0.000 \\
\hline 4 & & SR 4 & 0.819 & 0.000 & 0.000 & 0.000 & 0.000 & 0.000 \\
\hline 5 & \multirow[t]{5}{*}{ Social Sharing (SS) } & SS 1 & 0.000 & 0.732 & 0.000 & 0.000 & 0.000 & 0.000 \\
\hline 6 & & \begin{tabular}{|l|} 
SS 2 \\
\end{tabular} & 0.000 & 0.857 & 0.000 & 0.000 & 0.000 & 0.000 \\
\hline 7 & & \begin{tabular}{|l|} 
SS 3 \\
\end{tabular} & 0.000 & 0.861 & 0.000 & 0.000 & 0.000 & 0.000 \\
\hline 8 & & \begin{tabular}{|l|} 
SS 4 \\
\end{tabular} & 0.000 & 0.831 & 0.000 & 0.000 & 0.000 & 0.000 \\
\hline 9 & & SS 5 & 0.000 & 0.867 & 0.000 & 0.000 & 0.000 & 0.000 \\
\hline 10 & \multirow[t]{3}{*}{ Open Mind (OM) } & $\mathrm{OM} 1$ & 0.000 & 0.000 & 0.831 & 0.000 & 0.000 & 0.000 \\
\hline 11 & & OM 2 & 0.000 & 0.000 & 0.909 & 0.000 & 0.000 & 0.000 \\
\hline 12 & & OM 3 & 0.000 & 0.000 & 0.843 & 0.000 & 0.000 & 0.000 \\
\hline 13 & \multirow[t]{2}{*}{ Intimacy (IN) } & IN 1 & 0.000 & 0.000 & 0.000 & 0.962 & 0.000 & 0.000 \\
\hline 14 & & IN 2 & 0.000 & 0.000 & 0.000 & 0.976 & 0.000 & 0.000 \\
\hline 15 & \multirow[t]{4}{*}{ Social Identity (SI) } & SI 1 & 0.000 & 0.000 & 0.000 & 0.000 & 0.851 & 0.000 \\
\hline 16 & & SI 2 & 0.000 & 0.000 & 0.000 & 0.000 & 0.745 & 0.000 \\
\hline 17 & & SI 3 & 0.000 & 0.000 & 0.000 & 0.000 & 0.740 & 0.000 \\
\hline 18 & & SI 4 & 0.000 & 0.000 & 0.000 & 0.000 & 0.786 & 0.000 \\
\hline 19 & \multirow[t]{4}{*}{ Academic Performance (AP) } & AP 1 & 0.000 & 0.000 & 0.000 & 0.000 & 0.000 & 0.914 \\
\hline 20 & & AP 2 & 0.000 & 0.000 & 0.000 & 0.000 & 0.000 & 0.901 \\
\hline 21 & & AP 3 & 0.000 & 0.000 & 0.000 & 0.000 & 0.000 & 0.938 \\
\hline 22 & & AP 4 & 0.000 & 0.000 & 0.000 & 0.000 & 0.000 & 0.920 \\
\hline
\end{tabular}

\subsection{Convergent validity of the measurements}

The composite reliability values differed from 0.862 to 0.968 and they are everywhere throughout the prescribed cut-off estimation of 0.70 , with Cronbach values contrasting from 0.789 to 0.938 , over the prescribed cut-off estimation of 0.60 . In addition, the normal change removed (AVE) values contrasted from 0.611 to 0.939 (all surpassed the cut-off estimation of 0.5 ), with critical element loadings surpassing 0.50 . These qualities all went over the prescribed an incentive by [40] and [41]. Table 3 presents the CFA results of the measurement model. 
Table 3. Convergent validity

\begin{tabular}{|c|c|c|c|c|c|c|}
\hline No & Variables & Code & Factors Loading & Composite Reliability & AVE & Cronbach's Alpha \\
\hline 1 & \multirow{4}{*}{ Social Respect (SR) } & SR 1 & 0.831 & \multirow{4}{*}{0.899} & \multirow{4}{*}{0.692} & \multirow{4}{*}{0.852} \\
\hline 2 & & SR 2 & 0.818 & & & \\
\hline 3 & & SR 3 & 0.858 & & & \\
\hline 4 & & SR 4 & 0.819 & & & \\
\hline 5 & \multirow[t]{5}{*}{ Social Sharing (SS) } & SS 1 & 0.732 & \multirow{5}{*}{0.918} & \multirow{5}{*}{0.691} & \multirow{5}{*}{0.887} \\
\hline 6 & & SS 2 & 0.857 & & & \\
\hline 7 & & SS 3 & 0.861 & & & \\
\hline 8 & & SS 4 & 0.831 & & & \\
\hline 9 & & SS 5 & 0.867 & & & \\
\hline 10 & \multirow[t]{3}{*}{ Open Mind (OM) } & OM 1 & 0.831 & \multirow{3}{*}{0.896} & \multirow{3}{*}{0.743} & \multirow{3}{*}{0.826} \\
\hline 11 & & OM 2 & 0.909 & & & \\
\hline 12 & & OM 3 & 0.843 & & & \\
\hline 13 & \multirow[t]{2}{*}{ Intimacy (IN) } & IN 1 & 0.962 & \multirow[t]{2}{*}{0.968} & \multirow[t]{2}{*}{0.939} & \multirow[t]{2}{*}{0.935} \\
\hline 14 & & IN 2 & 0.976 & & & \\
\hline 15 & \multirow[t]{4}{*}{ Social Identity (SI) } & SI 1 & 0.851 & \multirow{4}{*}{0.862} & \multirow{4}{*}{0.611} & \multirow{4}{*}{0.789} \\
\hline 16 & & SI 2 & 0.745 & & & \\
\hline 17 & & SI 3 & 0.740 & & & \\
\hline 18 & & SI 4 & 0.786 & & & \\
\hline 19 & Academic & AP 1 & 0.914 & \multirow{4}{*}{0.956} & \multirow{4}{*}{0.843} & \multirow{4}{*}{0.938} \\
\hline 20 & \multirow{3}{*}{ Performance (AP) } & AP 2 & 0.901 & & & \\
\hline 21 & & AP 3 & 0.938 & & & \\
\hline 22 & & $\mathrm{AP} 4$ & 0.920 & & & \\
\hline
\end{tabular}

\subsection{Discriminant validity of measures}

The level to which an idea and its pointers go astray from another idea and it's markers is surveyed by discriminant legitimacy (Bagozzi et al., 1991). The AVE esteem is well over 0.50 and is critical at $p=0.001$ and this shows that discriminant legitimacy is strengthened for the whole builds [40]. In such manner, Hair et al. [41] clarified that the relationships between things in two develops should not to exceed the square base of the normal fluctuation shared by a solitary develops things (See Table 4).

Table 4. Latent Variable Correlations

\begin{tabular}{|l|c|c|c|c|c|c|}
\hline \multicolumn{1}{|c|}{ Variables } & AP & IN & OM & SI & SR & SS \\
\hline Academic Performance (AP) & 1.000 & & & & & \\
\hline Intimacy (IN) & 0.317 & 1.000 & & & & \\
\hline Open Mind (OM) & 0.551 & 0.299 & 1.000 & & & \\
\hline Social Identity (SI) & 0.485 & 0.445 & .0656 & 1.000 & & \\
\hline Social Respect (SR) & 0.390 & 0.100 & 0.628 & 0.480 & 1.000 & \\
\hline Social Sharing (SS) & 0.576 & 0.329 & 0.622 & 0.562 & 0.601 & 1.000 \\
\hline
\end{tabular}




\subsection{Analysis of the structural model}

Taking after the assurance of the integrity of the demonstrated estimation, the following stride involved the testing of the conjectured connections among the builds. SmartPLS 2.0 was used to analyze the model by leading the PLS calculation. The path coefficients and path coefficient $\mathrm{T}$ values were then produced as depicted in Figure 2 and 3. Hypothesis testing is reported in table 5.

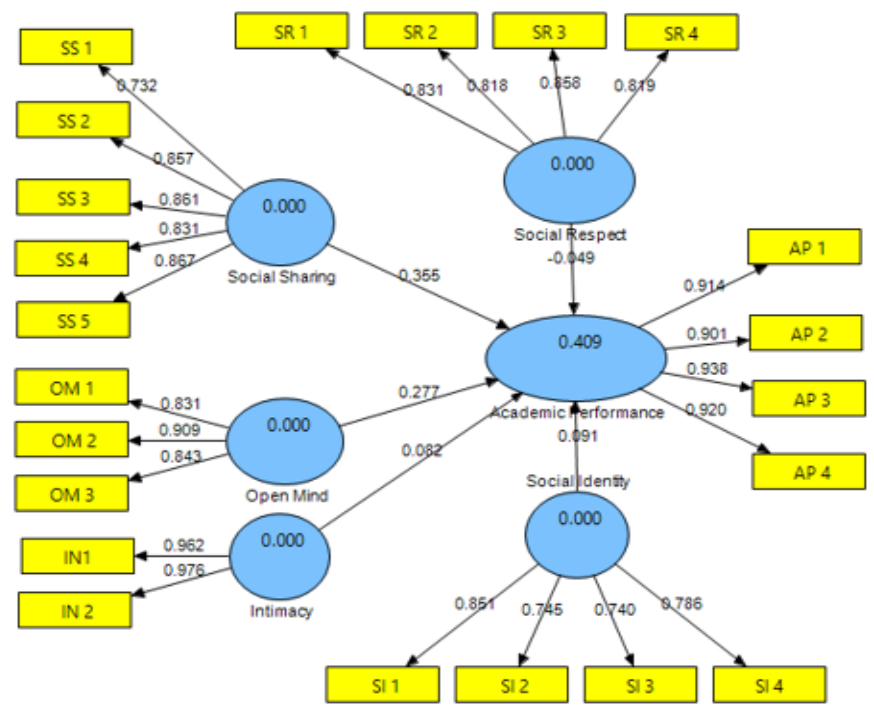

Fig. 2. Path Coefficients Results

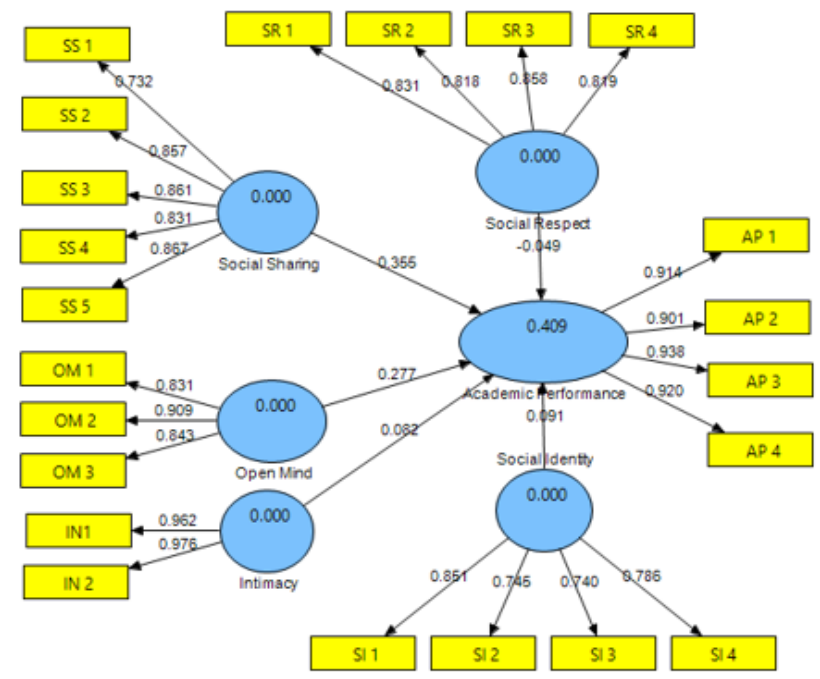

Fig. 3. Path Coefficients T Values 
This research has five hypotheses, all the proposed hypotheses were supported. Specifically, the results show positive and significant relationship between social respect and academic performance at $(\beta=0.049, \mathrm{t}=3.295, \mathrm{p}<0.001)$ which support the first hypothesis. Added to this, the results also show the relationship between social sharing and academic performance is positive and significant at $(\beta=0.355, \mathrm{t}=$ $26.999, \mathrm{p}<0.001)$ in support for the second hypothesis. Moreover, the results show positive and significant relationship between open mind and academic performance at $(\beta=0.277, t=18.333, p<0.001)$, showing support for the third hypothesis. Furthermore, relationship between intimacy and academic performance was found to be positive and significant at $(B=0.082, t=8.524, p<0.001)$ which reflect support for the fourth hypothesis. Finally, the fifth hypothesis was also supported as the relationship between social identity and academic performance found to be positive and significant at $(\beta=0.091, \mathrm{t}=6.897, \mathrm{p}<0.001)$.

Table 5. Hypothesis testing

\begin{tabular}{|l|l|l|l|c|c|c|l|}
\hline H & IV & Relationship & DV & $\begin{array}{c}\text { Path } \\
\text { coefficient }\end{array}$ & Standard. E & T Value & Result \\
\hline 1 & SR & $\longrightarrow$ & AP & 0.049 & 0.014 & 3.295 & Supported \\
\hline 2 & SS & $\longrightarrow$ & AP & 0.355 & 0.013 & 26.999 & Supported \\
\hline 3 & OM & $\longrightarrow$ & AP & 0.277 & 0.015 & 18.333 & Supported \\
\hline 4 & IN & $\longrightarrow$ & AP & 0.082 & 0.009 & 8.524 & Supported \\
\hline 5 & SI & $\longrightarrow$ & AP & 0.091 & 0.013 & 6.897 & Supported \\
\hline
\end{tabular}

\section{Discussion}

The general objective of this study is to propose a model that shows the facets of social presence that determine students' performance in online learning interaction through SNS. This study hypothesized that five facets of social presence to be significant in enhancing students' academic performance in online learning interaction through social networking sites SNS. The findings of the study revealed a significant link between each of the five facets of social presence on SNS and students' performance. Projecting of social respect, social sharing, open mind, intimacy and social identity are factors that boost students' academic performance. Social presence support students' performance as it gives them the sense, they are part of the learning community and their questions, ideas or point of views are welcomed by their teacher and peers.

Establishing friendly and close relationship among learning participants would motivate student's participation in more discussion as they feel their contribution is heard, considered and appreciated by other participants. Likewise, the findings indicated that it is important to develop more socialized and friendly learning environment in which student has the sense she/he is an important member of the learning community and can freely share stories with others. Evidently, this study findings support previous study which argued that SNS support friendly learning atmosphere and boost students sense of closeness which encourage sharing stories, ask questions and engage in more interaction [30]. In such environment students feel 
relax and motivated to participate more in the online discussion and learning activities. Therefore, previous studies recommended that more friendly and secure learning environment encourage more connection with other course members [42] and motivate students to participate more during online discussion [43] and [3].

Students are more willing to share their ideas, point of views on the discussed topics without worrying of being judged or ignored. Moreover, students are ready to post their questions, ask for more interpretation and explanation. In fact, sense of closeness to others gives learners the self-confidence to seek help and support from others when they face difficulties in their learning. In this instance, students are establishing a collaborative learning atmosphere which considered essential result of conveying social presence in online learning environment [44]. Consequently, participation in online discussion and collaboration with other course members indicate that students are actively playing their role in the learning process. However, previous studies also reported that students' with higher social presence takes active role in the learning process [3] and [4]. Consequently, student's involvement in more discussion and collaboration through providing answers or getting feedback from others are the keys for better academic performance. Unquestionably, SNS tools are getting more attention in the field of online and blended learning due the fact that they have the features to accommodate all types of student's sense of social presence in the learning community. This fact is supported by previous research findings which reported that SNS tools supported by its social nature accommodate social learning interaction and cultivated social presence to levels that contributed to building sense of closeness among learning community members and boosted academic performance $[26 ; 27 ; 28 ; 30 ; 33 ; 35 ; 45]$.

\section{Conclusion}

To conclude, it is obvious that social networking sites are heavily used by young people in the tertiary context. Educationally, SNS found to facilitate online learning interaction [24] and [25] supported by high level of social presence [26] and [31]. The aim of this study was to explore the impact of several facets of online social presence on SNS on students perceived academic performance. This study suggested that Sung and Mayer [2] five facets of social presence can be developed in the context of SNS to prompt learning and better academic performance. Students believe that SNS is the place where they established sense of belonging to the learning community with close and friendly relationship with the instructor and peers. Consequently, students expressed that they were socially respected, recognized and were able to freely express themselves and share their personal life stories.

Students with higher sense of social presence engage in more course online discussion [46] which lead to better learning and academic performance [27]. Hence, facets of social presence which are social respect, social sharing, open mind, intimacy and social identity found to have a strong relationship with students' academic performance. The findings reflect the role of social presence on online learning and the power of SNS to inspire the sense of social presence among learning participants. 
The findings of this study provide a valuable reference for instructors, researchers and instructional designers to use the five social presence facets model in the future online learning, online learning design and for online social presence research.

\section{Recommendations for Future Research}

Future studies need to find the role of mediating factors such as sense of privacy on SNS, year of study and gender that might affect the relationships between each of the five facets of SP and students' academic performance. Moreover, studies with larger number of participants and different tertiary levels is recommended to establish more consistent and stronger findings.

\section{Acknowledgement}

The authors would like to thank the Universiti Sains Malaysia (USM) for supporting this research project. This work was supported by the Short-Term Grant (304/PGURU/6315282) initiated by USM.

\section{Reference}

[1] C. S. Oh, J. N. Bailenson, and G. F. Welch, "A Systematic Review of Social Presence: Definition, Antecedents , and Implications," vol. 5, no. October, pp. 1-35, 2018.

[2] E. Sung and R. E. Mayer, "Five facets of social presence in online distance education," Comput. Human Behav., vol. 28, no. 5, pp. 1738-1747, 2012. https://doi.org/10.1016/j. chb.2012.04.014

[3] S. Whiteside, A; Dikkers, A and Lewis, "The Power of Social Presence for Learning," 2014. [Online]. Available: https://er.educause.edu/articles/2014/5/the-power-of-socialpresence-for-learning. [Accessed: 21-Nov-2018].

[4] Y. M. Al-dheleai and Z. Tasir, "Web 2.0 for Fostering Students' Social Presence in Online Learning-Based Interaction," J. Technol. Sci. Educ., vol. 9, no. 1, pp. 13-19, 2019. https:// doi.org/10.3926/jotse.552

[5] S. Joksimović, D. Gašević, V. Kovanović, B. E. Riecke, and M. Hatala, "Social presence in online discussions as a process predictor of academic performance," J. Comput. Assist. Learn., vol. 31, no. 6, pp. 1-37, 2015. https://doi.org/10.1111/jcal.12107

[6] J. C. Richardson, Y. Maeda, J. Lv, and S. Caskurlu, "Social presence in relation to students ' satisfaction and learning in the online environment: A meta-analysis," Comput. Human Behav., vol. 71, pp. 402-417, 2017. https://doi.org/10.1016/j.chb.2017.02.001

[7] L. Rourke, T. Anderson, D. R. Garrison, and W. Archer, "Assessing Social Presence I n Asynchronous Text-based Computer Conferencing,” J. Distance Educ., vol. 11, no. 4.2, pp. 1-18, 2001.

[8] J. Argyle, M. and Dean, "Eye-contact, Distance and Affiliation.” JSTOR, 1965.

[9] R. L. Heath and J. Bryant, Human communication theory and research: Concepts, contexts, and challenges. Routledge, 2013. 
[10] C. H. Tardy, "Social support: Conceptual clarification and measurement options," Tardy, CH (toim.), A Handb. study Hum. Commun. Methods instruments Obs. Meas. Assess. Commun. Process. Norwood Ablex, pp. 347-364, 1988.

[11] R. H. Cutler, "Distributed Presence and Community In Cyberspace," Cent. Teach. Technol. Acad. Comput. Center, Georg. Univ. Washington, DC, no. Cmc, pp. 1-14, 1995.

[12] D. R. Akyol, Z., \& Garrison, "The Community of Inquiry Theoretical Framework: In the Context of Online and Blended Learning D.," MERLOT J. Online Learn. Teach., no. Cmc, pp. 1-38, 2016.

[13] B. Chen, "Strategies for Creating a Community of Inquiry through Online Asynchronous Discussions," vol. 10, no. 1, pp. 153-165, 2014.

[14] E. Middendorf, J. \& Osborne, "Learning Student Names," Natl. Teach. Learn. Forum, 1997.

[15] S. Izmirli, "Can we use Facebook groups to establish social presence in online," World J. Educ. Technol., vol. 09, no. 4, pp. 173-182, 2017. https://doi.org/10.18844/wjet.v9i4.2558

[16] M. M. Merryfield, "Four Strategies for Teaching Open-Mindedness," vol. 25, no. 2, pp. 18-22, 2012.

[17] A. S. C. Leh, "Computer-mediated communication and social presence in a distance learning environment," Int. J. Educ. Telecommun., vol. 7, no. 2, pp. 109-128, 2001.

[18] N. A. John, "The social logics of sharing," Commun. Rev., vol. 16, no. 3, pp. 113-131, 2013.

[19] N. A. Cooke, "Information Sharing, Community Development, and Deindividuation in the eLearning Domain," Online Learn., vol. 20, no. 2, pp. 244-260, 2016. https://doi.org/ 10.24059/olj.v20i2.614

[20] E. Aydin, "The Relationship Between Teacher Immediacy Behaviors and Learners ' Perceptions of Social Presence and Satisfaction in Open and Distance Education: The Case of Anadolu University,” Turkish Online J. Educ. Technol., vol. 6, no. 4, 2007.

[21] J. C. Richardson, A. A. Koehler, E. D. Besser, S. Caskurlu, J. Lim, and C. M. Mueller, "Conceptualizing and Investigating Instructor Presence in Online Learning Environments," vol. 16, no. 3, pp. 256-297, 2015. https://doi.org/10.19173/irrodl.v16i3.2123

[22] K. Swan, "Building learning communities in online courses: The importance of interaction," Educ. Commun. Inf., vol. 2, no. 1, pp. 23-49, 2002.

[23] M. M. Alamri, "Undergraduate Students ' Perceptions toward Social Media Usage and Academic Performance: A Study from Saudi Arabia,” Int. J. Emerg. Technol. Learn., vol. 14, no. 3, pp. 61-79, 2019. https://doi.org/10.3991/ijet.v14i03.9340

[24] S. Al Hashimi, S., Al Muwali, A., Zaki, Y., Mahdi, N., "The Effectiveness of Social Media and Multimedia-Based Pedagogy in Enhancing Creativity among Art, Design , and Digital Media Students,” Int. J. Emerg. Technol. Learn., vol. 14, no. 21, pp. 176-190, 2019. https ://doi.org/10.3991/ijet.v14i21.10596

[25] Z. Tasir, Y. M. H. Al-dheleai, J. Harun, and N. A. Shukor, "Students 'Perception towards the Use of Social Networking as an e- learning Platform," 10th WSEAS Int. Conf. Educ. Educ. Technol. Penang Malaysia, pp. 70-75, 2011.

[26] Y. M. Al-dheleai and Z. Tasir, "Facebook to Facilitate Instructor Roles in Course-Related Online Interaction: A Pilot Study," J. Theor. Appl. Inf. Technol., vol. 89, no. 2, 2016.

[27] Y. M. Al-dheleai and Z. Tasir, "Using Facebook for the Purpose of Students' Interaction and its Correlation with Students 'Academic Performance," Turkish Online J. Educ. Technol., vol. 16, no. 4, pp. 170-178, 2017.

[28] J. C. Dunlap and P. R. Lowenthal, "Tweeting the Night Away: Using Twitter to Enhance Social Presence," vol. 20, 2009. 
[29] E. Öztürk, "Facebook as a new community of inquiry environment : An investigation in terms of academic achievement and motivation," J. Balt. Sci. Educ., vol. 14, no. 1, 2015.

[30] J. Lim and J. C. Richardson, "Internet and Higher Education Exploring the effects of students ' social networking experience on social presence and perceptions of using SNSs for educational purposes," Internet High. Educ., vol. 29, pp. 31-39, 2016. https://doi. org/10.1016/j.iheduc.2015.12.001

[31] A. Schroeder, S. Minocha, and C. Schneider, "Social Software in Higher Education: The Diversity of Applications and Their Contributions to Students ' Learning Experiences Contributions to Students ' Learning Experiences," vol. 26, 2010. https://doi.org/10.17705/ $\underline{1 \text { cais. } 02625}$

[32] S. C.-Y. Hung, Hsiu-Ting and Yuen, "Educational use of social networking technology in higher education,” Teach. High. Educ., vol. 15, no. 6, pp. 703-714, 2010.

[33] E. Baisley-nodine and A. D. Ritzhaupt, "Exploring social presence within an online course using Twitter," 2018. https://doi.org/10.1177/2042753018786004

[34] J. C. Richardson and K. Swan, "Examining social presence in online courses in relation to students' perceived learning and satisfaction," J. Asynchronous Learn. Netw., vol. 7, no. 1, pp. 68-88, 2003.

[35] Y. M. Al-dheleai and Z. Tasir, "Online Social Presence ' OSP' Patterns Correlation with Students' Academic Performance among Master of Education Program Students," vol. 13, no. 2, 2020. https://doi.org/10.29333/iji.2020.13234a

[36] A. G. Picciano, "Beyond student perceptions: Issues of interaction, presence, and performance in an online course," J. Asynchronous Learn. networks, vol. 6, no. 1, pp. 2140, 2002.

[37] Y. M. Al-dheleai, Z. Tasir, and N. F. Jumaat, "Depicting Students' Social Presence on Social Networking Site in Course-Related Interaction,” pp. 0-7, 2020. https://doi.org/10.11 77/2158244019899094

[38] N. Chen, C. Wei, and N. Chen, "A model for social presence in online classrooms," vol. 60, no. 3, pp. 529-545, 2012.

[39] Z. Zhan and H. Mei, "Academic self-concept and social presence in face-to-face and online learning: Perceptions and effects on students ' learning achievement and satisfaction across environments," Comput. Educ., vol. 69, pp. 131-138, 2013. https://doi. org/10.1016/j.compedu.2013.07.002

[40] C. Fornell and D. F. Larcker, "Evaluating structural equation models with unobservable variables and measurement error," J. Mark. Res., vol. 18, no. 1, pp. 39-50, 1981. https:// doi.org/10.1177/002224378101800104

[41] R. E. Hair, J. F., Black, W. C., Babin, B. J., \& Anderson, "Multivariate data analysis." Pearson Prentice Hall, 2010.

[42] Z. Sidiropoulou and I. Mavroidis, "The Relation Between the Three Dimensions of the Community of Inquiry and the Learning Styles of Students in a Distance Education Programme,” Int. J. Emerg. Technol. Learn., vol. 14, no. 23, pp. 180-192, 2019. https:// doi.org/10.3991/ijet.v14i23.11564

[43] M. M. Ilias, K., \& Nor, "Influence of Teacher-Student Interaction in The Classroom Behavior on Academic and Student Motivation In Teachers' Training Institute in Malaysia," vol. 2, no. 1, pp. 580-589, 2012.

[44] D. R. Garrison, "Article Review - Social Presence within the Community of Inquiry Framework," Int. Rev. Res. Open Distance Learn., vol. 12, 2011.

[45] A. A. Al-Rahmi, W. M., Alias, N., Othman, M. S., Ahmed, I. A., Zeki, A. M., \& Saged, "Social Media Use, Collaborative Learning And Students'academic Performance: A 
Systematic Literature Review Of Theoretical Models,” J. Theor. Appl. Inf. Technol., vol. 95, no. 20, 2017.

[46] Mohsen Saadatmand et al, "Examining Learners ' Interaction in an Open Online Course Through The Community of Inquiry Framework," Eur. J. Open, Distance e-Learning, vol. 20, no. 1, pp. 61-79, 2017. https://doi.org/10.1515/eurodl-2017-0004

\section{Authors}

Yahya M. Al-Dheleai is an educational technology senior lecturer at School of Educational Studies, Universiti Sains Malaysia. His research focus includes online learning, social media in education, Problem and Project-based learning, teaching and learning theories and strategies in online learning environment and startegies to improve students' 21st Century skills and practice. Email: yamohd3@gmail.com

Zaidatun Tasir is a professor of Educational Technology at the Department of Educational Science, Maths and Creative Multimedia, School of Education, faculty of Social Sciences and Humanities, Universiti Teknologi Malaysia (UTM). She is the dean of faculty of Social Sciences and Humanities, UTM. Her research interests and expertise include Design and Development of Computer and web-based Instructions, Multiple Intelligence through computer-based instruction, Problem-based learning through technology, Social Networking Tools in Education, and Online Social Learning Model. Email: p-zaida@utm.my

Waleed Mugahed Al-Rahmi is an assistant professor in the faculty of social sciences and humanities, school of education, Universiti Teknologi Malaysia. He was completed PhD degree from Faculty of Computing - Information Systems, Universiti Teknologi Malaysia. And he got Best Student Award, Doctor of Philosophy (Faculty of Computing - Information System), Excellent academic achievement in conjunction with the 56nd Convocation Ceremony, Universiti Teknologi Malaysia (UTM), 2016. Email: waleed.alrahmi@yahoo.com

Mohammed A. Al-Sharafi is currently a research fellow at the Faculty of Computing, Universiti Malaysia Pahang. He has MSc degree in Management Information System from Yarmouk University, Jordan. He's interested in research related to the Information Systems and technology management includes cloud computing, online social network, internet banking, e-learning, and technology adoption. Email: ma_shrafi@yahoo.com

Alamin Mydin is an Educational Management and Leadership senior lecturer in the School of Educational Studies, Universiti Sains Malaysia. Email: alamin@usm.my

Article submitted 2019-12-03. Resubmitted 2020-02-17. Final acceptance 2020-02-21. Final version published as submitted by the authors. 